\title{
Absence of blood parasites and other vector-borne pathogens in Alpine marmots (Marmota marmota) in Western Austria
}

\author{
Hans-Peter Fuehrer ${ }^{1}$ (D) $\cdot$ Ilona Soukup ${ }^{1} \cdot$ Bita Shahi-Barogh ${ }^{1} \cdot$ Walter Glawischnig ${ }^{2}$
}

Received: 10 September 2020 / Accepted: 7 December 2020 / Published online: 16 January 2021

(C) The Author(s) 2021

\begin{abstract}
The importance of vectors and vector-borne diseases (VBDs) is increasing on a global scale. Many vectors and pathogens benefit from global warming and can spread to novel habitats where they were formerly not present, including higher altitudes. Various vector-borne pathogens (VBPs), such as Anaplasma phagocytophilum, have been reported in, for instance, red foxes and wild ungulates in the Western Austrian Alps. However, these animals are known to migrate to lower regions in the winter season, and therefore, it is of interest to investigate if VBPs are also present in mammals faithful to their higher altitude alpine habitat all year round. Blood parasites and other VBPs, namely. Trypanosomatidae, piroplasms, Hepatozoon spp., filarioid helminths, Anaplasmataceae, and Rickettisa spp., were thus analysed with PCR in 148 alpine marmots (Marmota marmota). None of the marmots' blood samples was positive for these VBPs, indicating a low abundance or absence of competent vectors in the alpine region. Alpine marmots seem to be naïve for VBPs (at least in our study area). An overview of VBD agents in other marmot species is given.
\end{abstract}

Keywords Alps $\cdot$ Rodents $\cdot$ Babesia $\cdot$ Anaplasma phagocytophilum $\cdot$ Austria

\section{Introduction}

The impact of vector-borne diseases (VBDs) is increasing globally. VBDs are caused by various viruses, bacteria, protozoa, and helminths transmitted by competent vectors such as ticks, mosquitoes, sand flies, lice, and fleas. Lower temperatures at higher altitudes limit the development of VBDs and vector abundance (Zamora-Vilchis et al. 2012). Natural or human-driven environmental changes affect the ecological balance of hosts, vectors, and vector-borne pathogens (VBPs; Patz et al. 2000). Global warming influences the spread of VBPs and their vectors to areas where they were formerly not present. The increase of the daily average

Section Editor: Larissa Howe

Hans-Peter Fuehrer

hans-peter.fuehrer@vetmeduni.ac.at

1 Institute of Parasitology, Department of Pathobiology, University of Veterinary Medicine Vienna, Veterinärplatz 1, 1210 Vienna, Austria

2 Institute for Veterinary Disease Control Innsbruck, Austrian Agency for Health and Food Safety Ltd. (AGES), Technikerstrasse 70, 6020 Innsbruck, Austria temperature (even in alpine areas) allows faster development of pathogens in vectors (e.g. filarioid helminths). Moreover, moderate winter temperatures lead to the spread of vectors not only to northern regions (in the Northern hemisphere) but also to areas with higher altitudes. Wildlife plays an important role in establishment of vectors and VBDs (Tomassone et al. 2018). Recently, several studies have documented the presence of VBPs (such as Anaplasma phagocytophilum and various Babesia spp.) in wildlife from Alpine regions in Western Austria, for instance, red foxes, red deer, chamois, and Alpine ibex (Cézanne et al. 2017; Hodžić et al. 2018; Messner et al. 2019). However, wildlife analysed in previous studies is known to migrate from higher to lower altitudes in the winter season, and so might be exposed to vectors while at the lower altitudes. Information on the occurrence of VBDs in a mammal faithful to its alpine habitat is therefore of high interest.

The Alpine marmot (Marmota marmota) is a sciurid rodent distributed in the Alps (including the western parts of the Austrian Alps), Tatras, Carpathians, and Apennines and was reintroduced into various regions such as the Eastern Alps and Pyrenees (Preleuthner et al. 1995; Arnold 1999). The Alpine marmot is a remnant of the Pleistocene cold steppe, perfectly adapted to a colder climate (shown by its habit of hibernating and its use of burrows). Alpine marmots have low levels of 
genetic variation (among the lowest of all mammals), and climate-adapted life history traps show low genetic diversity (Gossmann et al. 2019). It can be found in a range of alpine altitudes, from the tree line up to $3000 \mathrm{~m}$ altitude. They are normally not documented at altitudes below $900 \mathrm{~m}$ (Preleuthner et al. 1995). This social ground-dwelling squirrel species is mainly herbivorous, living in alpine meadows in large groups. Knowledge regarding the parasite fauna in Alpine marmots is limited to intestinal helminths and protozoa and certain ectoparasites (Preleuthner et al. 1999). Four marmot-specific intestinal helminths are common in M. marmota-Ctenotaenia marmotae, Ascaris laevis, Citellina alpina, and Paranoplocephala transversaria (Preleuthner et al. 1999; Callait and Gauthier 2000). Zanet et al. (2017) reported a higher risk of gastrointestinal helminth infections at lower elevations in Alpine marmots. Moreover, several coccid protozoa such as Eimeria spp., Sarcocystis spp., and Toxoplasma gondii were documented (Preleuthner et al. 1999; Richter et al. 2007). Only very few ectoparasites were reported from M. marmota, namely Echinonyssus blanchardi, Neotrombicula autumnalis, and rarely Ixodes ricinus ticks (Preleuthner et al. 1999). Non-parasitic oribatids act as intermediate hosts of $C$. marmotae, which might be transported into burrows with nesting material (Ebermann 1976; Arnold and Lichtenstein 1993). The most important ectoparasite of Alpine marmots is E. blanchardi. Ticks were rarely documented because they are normally not present in the Alpine marmots' habitats (Alpine pastures above $1000 \mathrm{~m}$ ). Ix. ricinus was found in M. marmota populations living in lower regions (Arnold and Lichtenstein 1993). However, in the past decade, $I x$. ricinus was also regularly observed at altitudes up to and above $1700 \mathrm{~m}$ (personal communication, Gernot Walder; Messner et al. 2019; Garcia-Vozmediano et al. 2020).

At present, there is virtually no information regarding blood parasites and other VBPs in Alpine marmots. The aim of this study was to investigate the presence of various blood parasites and pathogens known to be present in wildlife in Western Austria, as well as VBDs described in other marmot species.

\section{Materials and methods}

A total of 148 blood samples were collected during the hunting season of 2018 (August 5-September 30) from Alpine marmots (Marmota marmota) in the Western Austrian provinces Tyrol and Vorarlberg. Whenever possible, age, sex, and additional remarks (such as intestinal helminths) were registered by the hunters. From each marmot, a blood sample (approx. $50 \mu \mathrm{l}$ ) was spotted on Whatman-filter paper (VWR International $\mathrm{GmBH}$, Vienna, Austria), air dried, and stored at room temperature. $4 \times 4 \mathrm{~mm}$ pieces of filter paper were cut out of the centre of the blood spot and DNA extraction processed as reported previously using an InstaGene ${ }^{\mathrm{TM}}$ matrix kit (BioRad Laboratories; Fuehrer et al. 2010). Samples were analysed for the presence of DNA of following vector-borne pathogens-Babesia and Hepatozoon (18S rRNA; BTH-1F/ BTH-1R; GF2/GR2), Trypanosomatida (18S rRNA; S762F/ S763R; TRnSSU-F2/TRnSSU-R2), filarioid nematodes ( $\mathrm{mt}$ COI; COIint-F/COIint-R), Anaplasmataceae (16S rRNA; EHR16SD/EHR16SR), and Rickettsia spp. (23S/5S rRNA; ITS-F/ITS-R) according to published protocols (Maslov et al. 1996; Brown et al. 2001; Casiraghi et al. 2001; Vitorino et al. 2003; Zintl et al. 2011; Seward et al. 2017; Messner et al. 2019). PCR products were analysed on $2 \%$ agarose gels stained with Midori Green Advance (Nippon Genetics Europe, Germany). PCR products showing bands were purified and sequenced at LGC Genomics GmbH (Germany).

\section{Results and discussion}

Blood samples of a total of 148 Alpine marmots were included in this study. Of those, 102 were collected in Tyrol and 46 in Vorarlberg (Table 1). Intestinal helminth infestations were noted in five animals. Moreover, one Alpine marmot presented with a systemic toxoplasmosis at histological examination.

None of the 148 Alpine marmots was positive for Anaplasmataceae, Rickettsia spp., Babesia spp., Hepatozoon spp., Trypanosomatida, or filarioid helminths. This is of special interest, since this demonstrates the absence or low abundance of vectors in the study area at $>1000 \mathrm{~m}$ above sea level.

In contrast, other marmot species - especially those living at lower altitudes - are common hosts of vector-borne pathogens.

Fifteen species of the genus Marmota occur in Asia, Europe, and Northern America (Herron et al. 2004; Brandler and Lyapunova 2009). Some species live in mountainous

Table 1 Sex, age class, and origin of Alpine marmots analysed in Western Austria

\begin{tabular}{llcccc}
\hline & District & Male & Female & Juvenile & Total \\
\hline Tyrol & Imst & 17 & 6 & 1 & 24 \\
& Innsbruck-Land & 18 & 14 & 2 & 34 \\
& Landeck & 15 & 5 & 0 & 20 \\
& Lienz & 15 & 5 & 3 & 23 \\
& Schwaz & 0 & 1 & 0 & 1 \\
Vorarlberg & Bludenz & 24 & 15 & 1 & 40 \\
& Bregenz & 1 & 3 & 1 & $6^{*}$ \\
& Total & 90 & 49 & 8 & 148 \\
\hline
\end{tabular}

*The sex/age of one marmot was unknown 
areas; others prefer rough grassland (and are so more prone to vector contact). Several VBD studies have been conducted in two North American marmot species-the groundhog (M. monax) and yellow-bellied marmot (M. flaviventris).

The groundhog or woodchuck (M. monax) is a North American marmot species preferring open country and edges of woodland. The parasite fauna and other vector-borne pathogens of groundhogs are well studied, and these animals are also used as laboratory animals (Fleming et al. 1979; Hilken et al. 2003). Various intestinal parasites but also ectoparasites are documented (Crouch 1936). Ix. cookei, Ix. hexagonus, Ix. dammini, and Dermacentor variabilis were found on M. monax (Crouch 1936; Magnarelli et al. 1991; Smith et al. 2019). Ixodes cookei ticks (so called groundhog ticks) are believed to play a role in the transmission of Powassan virus lineage 1 (Mlera and Bloom 2018). Groundhogs are thought to be potential wildlife reservoirs of Borrelia burgdorferi, but $I x$. cookei ticks have been shown to be ineffective vectors for this pathogen (Barker et al. 1993). A study conducted in Pennsylvania (USA) reported 58\% of 659 woodchucks seropositive for Ehrlichia chaffeensis (Nicholson et al. 2003). Moreover, woodchucks are exposed to spotted fever group rickettsiae (Magnarelli et al. 1991). Reeves et al. (2005) reported Rickettsia typhi in Enderleinellus marmotae (hostspecific louse) collected from M. monax in SC, USA. The vector capacity of E. marmotae for $R$. typhi remains unclear because several flea species including Pulex irritans feed on groundhogs (Reeves et al. 2005).

Ackertia marmotae is an onchocercid nematode in the liver of woodchucks. It is transmitted by Ix. cookei. In Tompkins County, New York (USA), this parasite was found in 78\% (151 of 194) of woodchucks (Fleming et al. 1979). A. marmotae is able to survive hibernation as 4th stage larvae (Fleming et al. 1979). Moreover, Hepatozoon sp. was documented in the whole blood of a single woodchuck in MO, USA (Allen et al. 2011).

The yellow-bellied marmot is native to mountainous areas in the USA and Canada and is found between 1600 and 4250 $m$ above sea level (Armstrong et al. 2010). In a study conducted in Yosemite National Park in California, Fleer et al. (2011) serologically screened one yellow-bellied marmot for various VBDs, and it tested positive for An. phagocytophilum (negative for Borrelia and Rickettsia spp.). Trypanosoma sp. was reported in M. flaviventer nosophora (Dias 1938) and yellowbellied marmots in Colorado (Nouri and Blumstein 2019). Lopez et al. (2013) documented flea- and louse-transmitted $T$. lewisi. They stated that age is significantly associated with infection, and yearlings are more likely to be infected.

Although marmots are associated with important pathogens such as Yersina pestis, there is a lack of knowledge about vector-borne pathogens in other marmot species. Various fleas of the genus Citellophilus (some species are vectors of $Y$. pestis) parasitize marmots and ground squirrels
(Medvedev et al. 2019). Ix. autumnalis was found on the Eurasian bobac marmot (M. bobac; Crouch 1936). The argasid tick Ornithodoros (Ornithodoros) huajianensis sp. nov. was described to be a parasite of the Mongolian marmot (M. bobak sibirica) in Gansu province, China (Sun et al. 2019). Walchia marmota sp. nov. is a trombiculid mite which parasitizes the Himalayan marmot (M. himalayana; Wen and Zhou 1997).

Overall the summary of various vector-borne pathogens and potential vectors shows that the genus Marmota harbours various VBDs. M. marmota seems to be naïve for VBDs, which might have a negative impact on Alpine marmot populations if vectors spread to higher altitudes. In contrast to migrating wildlife such as red foxes and wild ungulates, the Alpine marmot will be able to act as an indicator species to ascertain if certain vectors and vector-borne pathogens (e.g. An. phagocytophilum) have spread to alpine altitudes in the future.

Acknowledgements We would like to express our gratitude to the hunters who aided in sample acquisition. We wish to thank Judit Lazar for her help at project organization.

Funding Open Access funding provided by University of Veterinary Medicine Vienna.

\section{Compliance with ethical standards}

Conflict of interest The authors declare that they have no conflict of interest.

Ethical approval All animals which were sampled in this study were culled by professional huntsmen in strict accordance with the animal welfare act currently valid in Austria (BGB1. I no. 118/2004; modifications: BGB1. I no. 54/2007, BGBl. I no. $2 / 2008$, BGB1. I no. 35/2008, BGB1. I no. 80/2010, BGB1. I no. 114/2012, BGB1. I no. 80/2013, BGB1. I no. 61/2017, BGBl. I no. 148/2017, BGB1. I no. 37/2018, BGB1. I no. $86 / 2018)$. No animal was harmed for the purpose of sample acquisition.

Open Access This article is licensed under a Creative Commons Attribution 4.0 International License, which permits use, sharing, adaptation, distribution and reproduction in any medium or format, as long as you give appropriate credit to the original author(s) and the source, provide a link to the Creative Commons licence, and indicate if changes were made. The images or other third party material in this article are included in the article's Creative Commons licence, unless indicated otherwise in a credit line to the material. If material is not included in the article's Creative Commons licence and your intended use is not permitted by statutory regulation or exceeds the permitted use, you will need to obtain permission directly from the copyright holder. To view a copy of this licence, visit http://creativecommons.org/licenses/by/4.0/.

\section{References}

Allen KE, Yabsley MJ, Johnson EM, Reichard MV, Panciera RJ, Ewing SA, Little SE (2011) Novel Hepatozoon in vertebrates from the 
southern United States. J Parasitol 97(4):648-653. https://doi.org/ 10.1645/GE-2672.1

Armstrong DM, Fitzgerald J, Meaney CA (2010) Mammals of Colorado (2nd). University Press of Colorado. ISBN 9781607320487

Arnold W (1999) Allgemeine Biologie und Lebensweise des Alpenmurmeltiers (Marmota marmota). Stapfia 63:1-19

Arnold W, Lichtenstein AV (1993) Ectoparasite load decrease the fitness of alpine marmots (Marmota marmota) but not a cost of sociality. Behav Ecol 4:36-39

Barker IK, Lindsay LR, Campbell GD, Surgeoner GA, McEwen SA (1993) The groundhog tick Ixodes cookei (Acari: Ixodidae): a poor potential vector of Lyme borreliosis. J Wildl Dis 29(3):416-422. https://doi.org/10.7589/0090-3558-29.3.416

Brandler OV, Lyapunova EA (2009) Molecular phylogenies of the genus Marmota (Rodentia Sciuridae): comparative analysis. Ethol Ecol Evol 21:289-298

Brown GK, Martin AR, Roberts TK, Aitken RJ (2001) Detection of Ehrlichia platys in dogs in Australia. Aust Vet J 79(8):554-558

Callait MP, Gauthier D (2000) Parasite adaptation to hibernation in Alpine Marmots (Marmota marmota). In: Heldmaier G, Klingenspor M (eds) Life in the Cold. Springer, Berlin, pp 139146. https://doi.org/10.1007/978-3-662-04162-8_15

Casiraghi M, Anderson TJ, Bandi C, Bazzocchi C, Genchi C (2001) A phylogenetic analysis of filarial nematodes: comparison with the phylogeny of Wolbachia endosymbionts. Parasitology. 122 Pt 1: 93-103. https://doi.org/10.1017/s0031182000007149

Cézanne R, Mrowietz N, Eigner B, Duscher GG, Glawischnig W, Fuehrer HP (2017) Molecular analysis of Anaplasma phagocytophilum and Babesia divergens in red deer (Cervus elaphus) in Western Austria. Mol Cell Probes 31:55-58. https:// doi.org/10.1016/j.mcp.2016.07.003

Crouch H (1936) The animal parasites of the woodchuck (Marmota monax $\mathrm{L}$ ) with special reference to protozoa. Iowa State College J Sci 11:48-50

Dias E (1938) Trypanosoma de um roedor, Marmota flaviventris nosophora, achado em Montana, Estados Unidos. Libro Jubil. Prof. L. Travassos: 141-143. In: Gabel JR. (1961) Protozoa of the Mountain Marmot, Marmota flaviventer Audubon and Bachman, 1841. Trans Am Micro Soc. 80 (1): 43-53

Ebermann (1976) Oribatiden (Oribatei, Acari) als Zwischenwirte des Murmeltier-Bandwurmes Ctenotaenia marmotae Frölich, 1802 [Oribatids (Oribatei, Acari) as intermediate hosts of Ctenotaenia marmotae (Frölich, 1802), a tapeworm parasitic in marmots (author's transl)]. Z Parasitenkd 50(3):303-312. German. https://doi. org/10.1007/BF02462974

Fleer KA, Foley P, Calder L, Foley JE (2011) Arthropod vectors and vector-borne bacterial pathogens in Yosemite National Park. J Med Entomol 48(1):101-110. https://doi.org/10.1603/me10040

Fleming WJ, Georgi JR, Caslick JW (1979) Parasites of the woodchuck (Marmota monax) in Central New York State. Proc Helminthol Soc Wash 46(1):115-127

Fuehrer HP, Starzengruber P, Swoboda P, Ali Khan W, Matt J, Ley B, Thriemer K, Haque R, Yunus EB, Hossain SM, Walochnik J, Noedl $\mathrm{H}$ (2010) Indigenous Plasmodium ovale malaria in Bangladesh. Am J Trop Med Hygn 83(1):75-78. https://doi.org/10.4269/ajtmh.2010. 09-0796

Garcia-Vozmediano A, Krawczyk AI, Sprong H, Rossi L, Ramassa E, Tomassone L (2020) Ticks climb the mountains: ixodid tick infestation and infection by tick-borne pathogens in the Western Alps. Ticks Tick Borne Dis 11(5):101489. https://doi.org/10.1016/j.ttbdis. 2020.101489

Gossmann TI, Shanmugasundram A, Börno S, Duvaux L, Lemaire C, Kuhl H, Klages S, Roberts LD, Schade S, Gostner JM, Hildebrand F, Vowinckel J, Bichet C, Mülleder M, Calvani E, Zelezniak A, Griffin JL, Bork P, Allaine D, Cohas A, Welch JJ, Timmermann B, Ralser M (2019) Ice-age climate adaptations trap the Alpine marmot in a state of low genetic diversity. Curr Biol 29(10):17121720.e7. https://doi.org/10.1016/j.cub.2019.04.020

Herron MD, Castoe TA, Parkinson CL (2004) Sciurid phylogeny and the paraphyly of Holarctic ground squirrels (Spermophilus). Mol Phylogenet Evol 31(3):1015-1030. https://doi.org/10.1016/j. ympev.2003.09.015

Hilken G, Büttner D, Militzer K (2003) Three important endoparasites of laboratory woodchucks (Marmota monax) caught in the wild: Capillaria hepatica, Ackertia marmotae and Taenia crassiceps. Scand J Lab Anim Sci 30(3):151-156

Hodžić A, Mrowietz N, Cézanne R, Bruckschwaiger P, Punz S, Habler VE, Tomsik V, Lazar J, Duscher GG, Glawischnig W, Fuehrer HP (2018) Occurrence and diversity of arthropod-transmitted pathogens in red foxes (Vulpes vulpes) in western Austria, and possible vertical (transplacental) transmission of Hepatozoon canis. Parasitology 145(3):335-344. https://doi.org/10.1017/S0031182017001536

Lopez J, Wey TW, Blumstein DT (2013) Patterns of parasite prevalence and individual infection in yellow-bellied marmots. J Zool 291:296303

Magnarelli LA, Andreadis TG, Stafford KC 3rd, Holland CJ (1991) Rickettsiae and Borrelia burgdorferi in ixodid ticks. J Clin Microbiol 29(12):2798-2804. https://doi.org/10.1128/JCM.29.12. 2798-2804.1991

Maslov DA, Lukes J, Jirku M, Simpson L (1996) Phylogeny of trypanosomes as inferred from the small and large subunit rRNAs: implications for the evolution of parasitism in the trypanosomatid protozoa. Mol Biochem Parasitol 75(2):197-205. https://doi.org/10.1016/ 0166-6851(95)02526-X

Medvedev SG, Kotti BK, Verzhutsky DB (2019) Diversity of fleas (Siphonaptera), vectors of plague pathogens: the flea Citellophilus tesquorum (Wagner, 1898), a parasite of ground squirrels of the genus Spermophilus. Entmol Rev 99:565-579. https://doi.org/10. 1134/S0013873819050014

Messner M, Kayikci FN, Shahi-Barogh B, Harl J, Messner C, Fuehrer HP (2019) Screening of wild ruminants from the Kaunertal and other alpine regions of Tyrol (Austria) for vector-borne pathogens. Parasitol Res 118(9):2735-2740. https://doi.org/10.1007/s00436019-06412-9

Mlera L, Bloom ME (2018) The role of mammalian reservoir hosts in tick-borne flavivirus biology. Front Cell Infect Microbiol 8:298. https://doi.org/10.3389/fcimb.2018.00298

Nicholson WL, Kuhar DJ, Humphreys JG, Childs JE (2003) Serologic evidence for a novel Ehrlichia species in woodchucks (Marmota monax) from Pennsylvania, USA. Ann N Y Acad Sci 990:90-93. https://doi.org/10.1111/j.1749-6632.2003.tb07342.x

Nouri K, Blumstein DT (2019) Parasites are associated with noisy alarm calls. Front Ecol Evol 7:1-6. https://doi.org/10.3389/fevo.2019. 00028

Patz JA, Graczyk TK, Geller N, Vittor AY (2000) Effects of environmental change on emerging parasitic diseases. Int J Parasitol 30(12-13): 1395-1405. https://doi.org/10.1016/s0020-7519(00)00141-7

Preleuthner M, Pinsker W, Kruckenhauser L, Miller WJ, Prosl H (1995) Alpine marmots in Austria. The present population structure as a result of the postglacial distribution history. Acta Theriol 3:87-100

Preleuthner M, Calderola S, Lanfranchi P, Prosl H (1999) Parasiten des Alpenmurmeltieres (Marmota marmota): Systematik, Entwicklung, Verbreitung. Stapfia 63(146):77-92

Reeves WK, Nelder MP, Korecki JA (2005) Bartonella and Rickettsia in fleas and lice from mammals in South Carolina, U.S.A. J Vector Ecol 30(2):310-315

Richter S, Wernsdorf P, Glawischnig P, Bagó Z (2007) The Ultrastructure of bradyzoites and tissue cysts of an apicomplexan parasite found in woodchuck (Marmota marmota Lin.) - a case study. Microsc Microanal 13(Suppl 3):236-237. https://doi.org/10.1017/ S1431927607081184 
Seward EA, Votýpka J, Kment P, Lukeš J, Kelly S (2017) Description of Phytomonas oxycareni $\mathrm{n}$. sp. from the salivary glands of Oxycarenus lavaterae. Protist. 168(1):71-79. https://doi.org/10. 1016/j.protis.2016.11.002

Smith KA, Oesterle PT, Jardine CM, Dibernardo A, Huynh C, Lindsay R, Pearl DL, Nemeth NM (2019) Tick infestations of wildlife and companion animals in Ontario, Canada, with detection of human pathogens in Ixodes scapularis ticks. Ticks Tick Borne Dis 10(1): 72-76. https://doi.org/10.1016/j.ttbdis.2018.08.018

Sun Y, Xu R, Liu Z, Wu M, Qin T (2019) Ornithodoros (Ornithodoros) huajianensis sp. nov. (Acari, argasidae), a new tick species from the Mongolian marmot (Marmota bobak sibirica), Gansu province in China. Int J Parasitol Parasites Wildl 9:209-217. https://doi.org/10. 1016/j.ijppaw.2019.05.001

Tomassone L, Berriatua E, De Sousa R, Duscher GG, Mihalca AD, Silaghi C, Sprong H, Zintl A (2018) Neglected vector-borne zoonoses in Europe: Into the wild. Vet Parasitol 251:17-26. https://doi. org/10.1016/j.vetpar.2017.12.018

Vitorino L, Zé-zé L, Sousa A, Baacellar F, Tenreiro R (2003) rRNA intergenic spacer regions for phylogenetic analysis of Rickettsia species. Ann N Y Acad Sci 990:726-733
Wen T, Zhou M (1997) A new species of Walchia (Acariformes: Trombiculidae: Walchiinae) parasitic on marmota. Syst Appl Acarol 2:215-218

Zamora-Vilchis I, Williams SE, Johnson CN (2012) Environmental temperature affects prevalence of blood parasites of birds on an elevation gradient: implications for disease in a warming climate. PLoS One 7(6):e39208. https://doi.org/10.1371/journal.pone.0039208

Zanet S, Miglio G, Ferrari C, Bassano B, Ferroglio E, von Hardenberg A (2017) Higher risk of gastrointestinal parasite infection at lower elevation suggests possible constraints in the distributional niche of Alpine marmots. PLoS One 12(8):e0182477. https://doi.org/10. 1371/journal.pone. 0182477

Zintl A, Finnerty EJ, Murphy TM, de Waal T, Gray JS (2011) Babesias of red deer (Cervus elaphus) in Ireland. Vet Res 42:7. https://doi.org/ $10.1186 / 1297-9716-42-7$

Publisher's note Springer Nature remains neutral with regard to jurisdictional claims in published maps and institutional affiliations. 